\title{
A Literature Review of Self-Sacrificial Leadership
}

\author{
Hanbing Zhang, Maolin Ye \\ School of Management, Jinan University, Guangzhou, China \\ Email: hanbingzhang1109@163.com
}

Received 13 July 2016; accepted 6 August 2016; published 9 August 2016

Copyright (C) 2016 by authors and Scientific Research Publishing Inc.

This work is licensed under the Creative Commons Attribution International License (CC BY). http://creativecommons.org/licenses/by/4.0/

c) (i) Open Access

\begin{abstract}
In the ever-competitive global business environment, companies may fail to adapt to the environment due to crisis. In this situation, companies call for self-sacrificing leaders to help companies get out of the woods. Self-sacrificing leadership is a spirit or behavior manifesting the leader's willingness to take on various kinds of risks and losses for the sake of the benefits of the whole organization and the subordinates. We explored the dimension and measurement methods, In order to clarify the nature of self-sacrificing leadership and the theoretical boundary with other leadership, we make a comparison of self-sacrificing leadership and other leadership. Future research can strengthen the study on the concept, measurement methods of self-sacrificing leadership.
\end{abstract}

\section{Keywords}

\section{Self-Sacrificing Leadership, Self-Sacrifice Spirit, Self-Sacrifice Behavior, Leadership}

\section{Introduction}

Recently, the development of globalization and the ever-competitive global business environment make the companies face with lots of uncertainty and can not control the environment. Hence, companies increasingly need to adapt to the rules of the leadership of this business trend. For example, under the financial crisis, Citigroup CEO Pandit just earned \$ 1 annual salary before the company got the profitability ability again; its executives of China Eastern Airlines and other companies have had voluntary pay cuts when the company faced a crisis. These actions communicated to staff the positive signal to overcome crisis, effectively help companies out of the crisis. These examples show that the leader of the self-sacrificing behavior can effectively improve leadership effectiveness, helping enterprises adapt to a turbulent environment.

More and more scholars believe that leadership is an influence; this influence enables employees to go 
beyond self-interest, values and goals to pursue the goals of the organization (Bass, 1985; Burns, 1978). Studies show that, as a role model, if the leader made self-sacrifice for the organization of collective interests, he will have a huge influence on subordinates, especially in situations of uncertainty or crisis (Halverson, Holladay, Kazama, \& Quinones, 2004; Yorges, Weiss, \& Strickland, 1999); maybe he can impact subordinates to make prosocial behavior (Conger, Kanungo, Menon, \& Mathur, 1997; Hogan \& Kaiser, 2005; Lockwood, Jordan, \& Kunda, 2002), build trust among employees, enhance loyalty, improve performance, etc. (De Cremer, 2006; Van Knippenberg \& Van Knippenberg, 2005).

In summary, in terms of theory or practice, self-sacrificing leadership is an important type of leadership, but related review article is very few. Therefore, this article will integrate theoretical and empirical research on the concept, structure and methods of measurement of self-sacrificing leadership; what's more, we will make a comparison among self-sacrificing leadership and other types of leadership and sort out the antecedents and consequences.

\section{The Concept of Self-Sacrifice Leadership}

Currently, different scholars put forward different views on the concept of self-sacrificing leadership according to their own research purposes, and academia has not yet formed an shared definition. to complete presentation of the connotation of self-sacrificing leadership, we sort out the concept of self-sacrifice Leadership from traits, behavior two perspectives. In the trait perspective, self-sacrificing leadership is that the leader has a willingness to take risks and loss of self-sacrifice (Yorges et al., 1999; Mulder \& Nelissen, 2010). Also it's a strong responsibility of organizational affairs and member satisfaction, a carement for employee needs (De Cremer et al., 2009). In the behavior perspective, self-sacrificing leadership is that, the leader shows a kind of self-sacrificing behavior in the manegement of organization. For example, Choi and Mai-Dalton (1998) believes that self-sacrificing leadership means the leader voluntary temporarily or permanently give up personal interests, privileges and welfare for the interests of the organization (Hoogervorst et al., 2012; Bout, 2013). De Cremer et al. (2004) think that the self-sacrificing leadership means leader who are committed to the objectives and tasks of the team or the organization voluntarily take actions that may bring individual risk behaviors (De Cremer, 2006).

In summary, the self-sacrificing leadership is to put personal interests before the welfare of subordinates on motivation, is willing to endure the loss or the risk on behavior, it is not a formal order, but in the interaction subtle influence subordinates to make voluntary change attitude and behavior on affecting mechanism.

\section{Dimensions and Measurement of Self-Sacrificing Leadership}

Scholars' study focused mostly on the connotation of the concept and definition of empirical research, and research on its structure and the measurement is few.

\subsection{Dimensions of Self-Sacrificing Leadership}

Choi and Mai-Dalton (1998) radical self-sacrificing leadership and incremental self-sacrificing leadership depending on the context and frequency of the self-sacrifice behavior. The former represents self-sacrificing behavior happened in a particular context (such as organizational crisis), the frequency is relatively small; the latter showing self-sacrificing behavior in general organizational context, high repeatability, and has been fixed as an act mode.

Matteson and Irving (2006) explore the common components in psychological characteristics by comparing the intrinsic characteristics of self-sacrifice, leadership and servant leadership, infer that dimensions of selfsacrificing leadership should include attitudes and behavior dimension. Attitude dimension components include: Love, altruistic tendencies, confidence and far-sighted. Behavioral dimensions include: altruism, initiative, empathy, role of demonstration, development and service subsidiary, to build community, provide leadership and common vision, enabling.

\subsection{Measurement of Self-Sacrificing Leadership}

The scales that researchers use can be divided into three scales. First, the researchers directly taken from the individual risk dimension in the Charismatic Leadership Scale (CK scale) (De Cremer, van Dijke, \& Bos, 2004; De Cremer \& van Knippenberg, 2005). This type of scale have single dimension and few entries, but has higher 
internal consistency (Table 1).

Secondly, researchers have developed scales whose content extracted from Choi and Mai-Dalton's (1998, 1999) operational definitions and experiments (Jeongkoo Yoon, 2006; Singh \& Krishnan, 2008). Such as Singh and Krishnan's scale (2008) which on the basis of the development of a self-sacrificing leadership, initially a total of 13 items, using five-point Likert scale, the analysis was carried out to explore the factors, culminating contains 6 single dimension self-sacrificing behavior scale items.

Finally, the development of multi-scale self-sacrificing leadership is developed on the basis of the content of the two scales together (Ruggieri \& Abbate, 2013; Hoogervorst et al., 2012; De Cremer et al., 2009; van Knippenberg \& van Knippenberg, 2005; De Cremer \& van Knippenberg, 2004). De Cremer et al. (2009) developed a scale on the basis of C-K, including three entries, $\alpha$ was 0.73 .

In summary, the current structure of the self-sacrificing leadership dimensions are not clear, there is no universally accepted scales, researchers need to further revise and develop well-structured measurement tools with high reliability and validity.

\section{The Comparison of Self-Sacrificing Leadership and Other Leadership}

Self-sacrificing leadership as a new theory of leadership, both leadership theory and other a lot in common, and there are essential differences. In order to clarify the nature of these types of connotation and leadership style of the intrinsic link with the theoretical boundary, explain clear leadership of self-sacrifice, As a new theory of leadership, Self-sacrificing leadership shares lots of characteristics with other leadership. and there are also essential differences. In order to clarify the nature of Self-sacrificing leadership and the theoretical boundary with other leadership, we make a comparison of self-sacrificing leadership and other leadership

\subsection{Self-Sacrificing Leadership vs Servant Leadership}

Servant leaders focus on human development of people, the establishment of the community, to show good faith for the members of the organization, the common interests of the entire organization and its clients while sharing power and status (Laub, 1999). Servant leadership has four dimensions, namely trait dimension, interpersonal dimension, the task dimension and process dimension. The theoretical basis is social exchange theory. the theory contend that the people's behavior is a reciprocal behavior essentially, that is, once one provide help and support to the other, the other one would feel responsibility to return. Both servant leadership and self-sacrificing are subordinate-oriented leadership, their leadership motivation including altruism ingredients, but they are different in the way to achieve a positive outcome, self-sacrificing leadership is by sacrificing their own interests to protect

Table 1. Measurement of self-sacrificing leadership.

\begin{tabular}{|c|c|c|c|}
\hline Scholar & Source & Sample & Number \\
\hline De Cremer et al. (2004) & & $\begin{array}{l}\text { My supervisor takes high personal risks for the } \\
\text { sake of the organization. }\end{array}$ & 2 \\
\hline Guofeng Wang (2013) & Taken from C-K scale & $\begin{array}{l}\text { Takes high personal risks for the sake of the } \\
\text { organization }\end{array}$ & 3 \\
\hline $\begin{array}{l}\text { De Cremer and van } \\
\text { Knippenberg (2004) }\end{array}$ & & $\begin{array}{l}\text { My supervisor is willing to make personal } \\
\text { sacrifices in the teams interest }\end{array}$ & 5 \\
\hline De Cremer et al. (2006) & Adapted from C-K scale & $\begin{array}{l}\text { My boss is somebody who shows a lot of } \\
\text { self-sacrifice }\end{array}$ & 3 \\
\hline $\begin{array}{l}\text { Singh and Krishnan } \\
\text { (2007) }\end{array}$ & $\begin{array}{l}\text { Adapted from Choi and Mai-Dalto’s } \\
\text { Operational definition (1998, 1999) }\end{array}$ & $\begin{array}{l}\text { Voluntarily gives up or refrains from exercising } \\
\text { or using his/her authority, position power or } \\
\text { privileges for own benefit }\end{array}$ & 13 \\
\hline Hoogervorst et al. (2012) & & $\begin{array}{l}\text { My supervisor is not willing to give up privileges } \\
\text { if the team needs this. }\end{array}$ & 2 \\
\hline $\begin{array}{l}\text { van Knippenberg and van } \\
\text { Knippenberg (2005) }\end{array}$ & $\begin{array}{l}\text { Adapted from Choi and Mai-Dalto’s } \\
\text { operational definition (1998, 1999) }\end{array}$ & $\begin{array}{l}\text { My supervisor is always among the first to sacrifice } \\
\text { free time, privileges, or comfort if that is important } \\
\text { for the team's mission }\end{array}$ & 2 \\
\hline
\end{tabular}


or safeguard the interests of member and organizations; while servant leadership is the spur the internal motivation by providing resources to meet the needs of the interests of members in organization, in order to stimsulate subordinates.

\subsection{Self-Sacrificing Leadership vs Charismatic Leadership}

Charming is a attributing phenomenon, it depends on the personality and behavioral characteristics of a leader, but also the personality traits related to followers. Charismatic leaders make followers worship leader, identity and desire to imitate the leader (Bass, 1985). It is based on the theory of attribution theory. Attribution theory support that people have a tendency to make inferences to psychological characteristics, qualities, personality differences of the actors according to people's behavior and its consequences. Both charismatic leadership and self-sacrificing leadership emphasize that leader could influence subordinates through their own behavior and attitude so as to enhance leadership. The first difference is the motivation. The motivation of self-sacrificing leaderships is altruism, while the motivation of charismatic leadership may be altruism or egoism. There are two types of charismatic leaders, one is socialized leadership and the other one is personalized leadership. That means charismatic leaders can use their charm for justice or evil service (Howell \& Shamir, 2005).

\subsection{Self-Sacrificing Leadership vs Transformational Leadership}

Transformational leadership can make employees aware of the importance of the tasks by stimulating subordinates' high-level need to establish an atmosphere of mutual trust, so as to sacrifice their own interests to promote the interests of the organization (Bass, 1985), it's based on Maslow's hierarchy of needs theory. The human needs can be divided into five kinds from low to high, including physiological need, safety needs, social interaction needs, respect needs and self-realization need. after people meet or partially meet lower levels of demand. they will pursuit of high-level requirements. The largest common characteristic of self-sacrificing leadership and transformational leadership is that the fundamental goal is to achieve organizational goals and organizational interests. The difference is that if the leaders themselves will suffer a loss. in order to achieve organizational goals self-sacrificing leadership emphasizes that the leader will make some self-sacrifice, indirectly influence of the perception, legitimacy and trust in the process; but transformational leadership may not have to sacrifice their own interests.

\subsection{Self-Sacrificing Leadership vs Benevolent Leadership}

Benevolent leadership refers to the leader who shows an individual, comprehensive and long-term care of the subordinate individual well-being (Fan Jingli, Bor Xun, 2000). It is based on the Confucian kindheartedness. Confucian kindheartedness advocates that filial piety, beloved brother practice extended to the whole of society, so form “All men are brothers” broad-mindedness. Both self-sacrificing leadership or benevolent leadership are able to inspire subordinates to follow the leader and put more intrinsic motivation to work hard. The biggest difference between the two lies in the attention to the needs of subordinates. Self-sacrificing leadership focus on the needs of subordinates in work, but it is indirect and one-sided. benevolent leadership concern for the needs of subordinates direct and comprehensive, not only focus on career development, but also extended to the magnanimity of his personal life.

\section{Prospects}

As a new style of leadership, self-sacrificing leadership is getting more and more attention from scholars. However, researches in this field is still relatively limited and not systematic. So we make prospects so as to help explore the leadership further.

\subsection{The Concept}

The concept of self-sacrificing leadership is mostly based on the definition of leadership behavior perspective, and extract from the relevant characteristics from behavior of leaders. Also the other perspective also exist inadequate, as the trait perspective, although Yorges et al. (1999) put forward that the self-sacrificing leadership is "willing to bear various forms of the losses and risks in personal beliefs, interests, etc.” but what's the specific 
components of this willingness, and whether it is kind of stable trait, or whether there are other psychological factors play a role? The researchers did not give the answer. Therefore, the concept of self-sacrificing leadership needs to be further refined and theoretical summary.

\subsection{Measurement Method}

Since the exploration of self-sacrificing leadership structure is still in the blank. Most scholars have used a scale from charismatic leadership style scale C-K, as well as extract from Choi and Mai-Dalton's $(1998,1999)$ operational definitions and experiments. Only a few scholars used exploratory factor analysis and confirmatory factor analysis to develop the relevant scale (Singh \& Krishman, 2007). Both the lack of amount of the empirical research and the development of self-sacrificing leadership studies calls for exploring the dimension, structure and high quality questionnaire of self-sacrificing leadership.

\section{References}

Bass, B. M. (1985). Leadership and Performance beyond Expectations. Free Press; Collier Macmillan.

Bout, D. (2013). The Impact of Company Grade Officer Self-Sacrificial Behavior on Subordinate Assessments of Leader Charisma. Doctoral Dissertation, Walden University.

Burns, J. M. (1978). Leadership. New Yorker: Harper \& Row.

Choi, Y., \& Mai-Dalton, R. R. (1998). On the Leadership Function of Self-Sacrifice. The Leadership Quarterly, 9, $475-501$. http://dx.doi.org/10.1016/S1048-9843(98)90012-1

Choi, Y., \& Mai-Dalton, R. R. (1999). The Model of Followers’ Responses to Self-Sacrificial Leadership: An Empirical Test. The Leadership Quarterly, 10, 397-421. http://dx.doi.org/10.1016/S1048-9843(99)00025-9

Conger, J. A., Kanungo, R. N., Menon, S. T., \& Mathur, P. (1997). Measuring Charisma: Dimensionality and Validity of the Conger-Kanungo Scale of Charismatic Leadership. Canadian Journal of Administrative Sciences/Revue Canadienne des Sciences de l'Administration, 14, 290-301. http://dx.doi.org/10.1111/j.1936-4490.1997.tb00136.x

De Cremer, D. (2006). Affective and Motivational Consequences of Leader Self-Sacrifice: The Moderating Effect of Autocratic Leadership. The Leadership Quarterly, 17, 79-93. http://dx.doi.org/10.1016/j.leaqua.2005.10.005

De Cremer, D., \& Van Knippenberg, D. (2004). Leader Self-Sacrifice and Leadership Effectiveness: The Moderating Role of Leader Self-Confidence. Organizational Behavior and Human Decision Processes, 95, 140-155.

http://dx.doi.org/10.1016/j.obhdp.2004.04.002

De Cremer, D., \& Van Knippenberg, D. (2005). Cooperation as a Function of Leader Self-Sacrifice, Trust, and Identification. Leadership \& Organization Development Journal, 26, 355-369. http://dx.doi.org/10.1108/01437730510607853

De Cremer, D., Mayer, D. M., van Dijke, M., Schouten, B. C., \& Bardes, M. (2009). When Does Self-Sacrificial Leadership Motivate Prosocial Behavior? It Depends on Followers' Prevention Focus. Journal of Applied Psychology, 94, 887-899. http://dx.doi.org/10.1037/a0014782

De Cremer, D., van Dijke, M., \& Bos, A. (2004). Distributive Justice Moderating the Effects of Self-Sacrificial Leadership. Leadership \& Organization Development Journal, 25, 466-475. http://dx.doi.org/10.1108/01437730410544773

Halverson, S. K., Holladay, C. L., Kazama, S. M., \& Quiñones, M. A. (2004). Self-Sacrificial Behavior in Crisis Situations: The Competing Roles of Behavioral and Situational Factors. The Leadership Quarterly, 15, 263-275. http://dx.doi.org/10.1016/j.leaqua.2004.02.001

Hogan, R., \& Kaiser, R. B. (2005). What We Know about Leadership. Review of General Psychology, 9, 169-180. http://dx.doi.org/10.1037/1089-2680.9.2.169

Hoogervorst, N., De Cremer, D., van Dijke, M., \& Mayer, D. M. (2012). When Do Leaders Sacrifice?: The Effects of Sense of Power and Belongingness on Leader Self-Sacrifice. The Leadership Quarterly, 23, 883-896. http://dx.doi.org/10.1016/j.leaqua.2012.05.006

Howell, J. M., \& Shamir, B. (2005). The Role of Followers in the Charismatic Leadership Process: Relationships and Their Consequences. Academy of Management Review, 30, 96-112. http://dx.doi.org/10.5465/AMR.2005.15281435

Lockwood, P., Jordan, C. H., \& Kunda, Z. (2002). Motivation by Positive or Negative Role Models: Regulatory Focus Determines Who Will Best Inspire Us. Journal of Personality and Social Psychology, 83, 854-864. http://dx.doi.org/10.1037/0022-3514.83.4.854

Matteson, J. A., \& Irving, J. A. (2006). Servant Versus Self-Sacrificial Leadership: A Behavioral Comparison of Two Follow-Oriented Leadership Theories. International Journal of Leadership Studies, 2, 36-51.

Mulder, L. B., \& Nelissen, R. M. (2010). When Rules Really Make a Difference: The Effect of Cooperation Rules and 
Self-Sacrificing Leadership on Moral Norms in Social Dilemmas. Journal of Business Ethics, 95, 57-72. http://dx.doi.org/10.1007/s10551-011-0795-z

Ruggieri, S., \& Abbate, C. S. (2013). Leadership Style, Self-Sacrifice, and Team Identification. Social Behavior and Personality: An International Journal, 41, 1171-1178. http://dx.doi.org/10.2224/sbp.2013.41.7.1171

Singh, N., \& Krishnan, V. R. (2008). Self-Sacrifice and Transformational Leadership: Mediating Role of Altruism. Leadership \& Organization Development Journal, 29, 261-274. http://dx.doi.org/10.1108/01437730810861317

Van Knippenberg, B., \& Van Knippenberg, D. (2005). Leader Self-Sacrifice and Leadership Effectiveness: The Moderating Role of Leader Prototypicality. Journal of Applied Psychology, 90, 25-37. http://dx.doi.org/10.1037/0021-9010.90.1.25

Yorges, S. L., Weiss, H. M., \& Strickland, O. J. (1999). The Effect of Leader Outcomes on Influence, Attributions, and Perceptions of Charisma. Journal of Applied Psychology, 84, 428. http://dx.doi.org/10.1037/0021-9010.84.3.428

\section{Submit or recommend next manuscript to SCIRP and we will provide best service for you:}

Accepting pre-submission inquiries through Email, Facebook, LinkedIn, Twitter, etc.

A wide selection of journals (inclusive of 9 subjects, more than 200 journals)

Providing 24-hour high-quality service

User-friendly online submission system

Fair and swift peer-review system

Efficient typesetting and proofreading procedure

Display of the result of downloads and visits, as well as the number of cited articles

Maximum dissemination of your research work

Submit your manuscript at: http://papersubmission.scirp.org/ 